\title{
Sting microsculpture in the digger wasp Bembix rostrata (Hymenoptera, Crabronidae)
}

\author{
Natalia A. Matushkina \\ Department of Zoology, Biological Faculty, Kyiv National University, 64 Volodymirs'ka St., Kyiv-01033, Ukraine \\ Corresponding author: Natalia A. Matushkina (odonataly@gmail.com)
}

Academic editor: Stefan Schmidt | Received 2 December 2010 | Accepted 8 December 2010 | Published 10 March 2011

Citation: Matushkina NA (2011) Sting microsculpture in the digger wasp Bembix rostrata (Hymenoptera, Crabronidae). Journal of Hymenoptera Research 21: 41-52. doi: 10.3897/JHR.21.873

\begin{abstract}
The sting microsculpture of the digger wasp Bembix rostrata (Fabricius, 1781) (Hymenoptera, Crabronidae) is studied with the scanning electron microscope (SEM) for the first time. As in many other hymenopterans, the second valvifer of $B$. rostrata possesses two fields of styloconic sensilla (hair plates) of proprioceptive function. The presence of two paired fields of campaniform sensilla on the second valvula and second valvifer is first shown in an apoid wasp. The first and the second valvulae bear scattered sensilla-like structures on the external surface, more numerous apically. The first valvula has two subapical barbs externally and a pair of valvilli on its inner surface, whereas the outer surface of the second valvula is smooth. The third valvula is sclerotized externally, consisting of proximal and distal parts, and bearing four sensilla morphotypes of mechanoreceptive and probably chemoreceptive functions. The inner surface of the valvulae and the membranous cuticle that is touching the sting have microstructures of different shapes directed distally. Functional aspects of characters studied are discussed.
\end{abstract}

\section{Keywords}

Morphology, sting apparatus, ovipositor

\section{Introduction}

The Hymenoptera are the sole group of endopterygote insects with a well-developed ovipositor, a plesiomorphic retention that has been considered one of the key factors in their diversification (Gauld and Bolton 1988). Besides oviposition, it can perform a number of other functions including sawing a substrate; location, discrimination 
and marking of the host; envenomation; stinging etc. (Quicke et al. 1999). In most Aculeata, the ovipositor has lost the primary function of an egg transporting device and is used as a sting to paralyse and rarely to transport the prey or as defense weapon (Rasnitsyn 1980, Radović 1985, Radović and Sušić 1997).

There are numerous classic works on morphology and functions of the hymenopterous ovipositor (e.g., Snodgrass 1956, Oeser 1961, Scudder 1961, Smith 1970, Quicke et al. 1999, Vilhelmsen 2000, Vilhelmsen et al. 2001, Packer 2003). Several publications dealt especially with microsculptural characters which have been used for phylogenetic reconstructions in some groups, mainly parasitic wasps (e.g., Quicke et al. 1992, 1999, Le Ralec et al. 1996, Nénon et al. 1995, Rahman et al. 1998). Both the comparative and functional aspects of the sting apparatus have been investigated extensively throughout some groups of the Apoidea (for review see Radović 1985, Packer 2003, Cardinal and Packer 2007), however only a few species of apoid wasp were explored in this respect (see review in Gadallah 2001). As a sister group of bees, the Crabronidae have gained insufficient attention during the last 10 years (Gadallah 2001, Packer 2003, Gadallah and Assery 2004). Generalizations concerning the sting structure in apoid wasps are still needed, though some attempts to compare sting morphology across several groups of apoid wasps have been made (Gadallah 2001, Gadallah and Assery 2004). Surprisingly, microstructure characters including sensory structures have not been discussed in the literature, except for a few general comments on the presence and distribution of some sensilla (Radović and Sušić 1997, Gadallah and Assery 2004). To the best of my knowledge, more detailed information on the sting microsculpture in apoid wasps is not available. The purpose of this study is to describe sting microsculpture in the digger wasp Bembix rostrata (Fabricius, 1781) (Hymenoptera, Crabronidae) using scanning electron microscopy in order to consider its possible functional use.

\section{Materials and methods}

Six females of B. rostrata were collected in Central Ukraine (Kyiv Province, Vyshgorodsky District, surroundings of village Khotyanivka, July 2008; 50³4'55"N $30^{\circ} 33^{\prime} 51$ "E). The gaster was removed from the wasp body using forceps, cut open slightly and macerated in $10 \% \mathrm{KOH}$. The sting apparatus was subsequently excised from the genital chamber, washed in water and examined in glycerine under a stereo microscope. For SEM study, the cuticular parts were washed in distilled water, dehydrated in a graded ethanol series and acetone, critical point dried (OM CPD 7501), coated with gold-palladium (OM-SC7640) and examined with a Zeiss EVO50 SEM (Museum of Zoology, Natural History Senckenberg Collections Dresden, Germany).

The terms used are preferably from Vilhelmsen et al. 2001, but also from Quicke et al. 1999, Gnatzy and Volknandt 2000 and Packer 2003. The following abbreviations were used: ap, apical process of inner membranous wall of $3^{\text {rd }}$ valvula; au, aulax; 
blb, bulb of the $2^{\text {nd }}$ valvula; dv, ductus venatus (= venom duct); rh, rhachis; rp, rostral process of $2^{\text {nd }}$ valvifer; $r 1$, ramus of the $1^{\text {st }}$ valvula; $r 2$, ramus of the $2^{\text {nd }}$ valvula; T9, tergum 9; vlv, valvilli; 1 vf, $1^{\text {st }}$ valvifer; $1 \mathrm{vv}, 1^{\text {st }}$ valvula; $2 \mathrm{vf}, 2^{\text {nd }}$ valvifer; $2 \mathrm{vv}, 2^{\text {nd }}$ valvula; $3 \mathrm{vv}, 3^{\text {rd }}$ valvula.

\section{Results}

General organization of the sting apparatus (Figs 1, 2A, B). The sting apparatus of $B$. rostrata lies within the genital chamber formed by the partial infolding of the $8^{\text {th }}$ and $9^{\text {th }}$ abdominal segments $\left(7^{\text {th }}\right.$ and $8^{\text {th }}$ metasomal segments) into the $7^{\text {th }}$ abdomi-

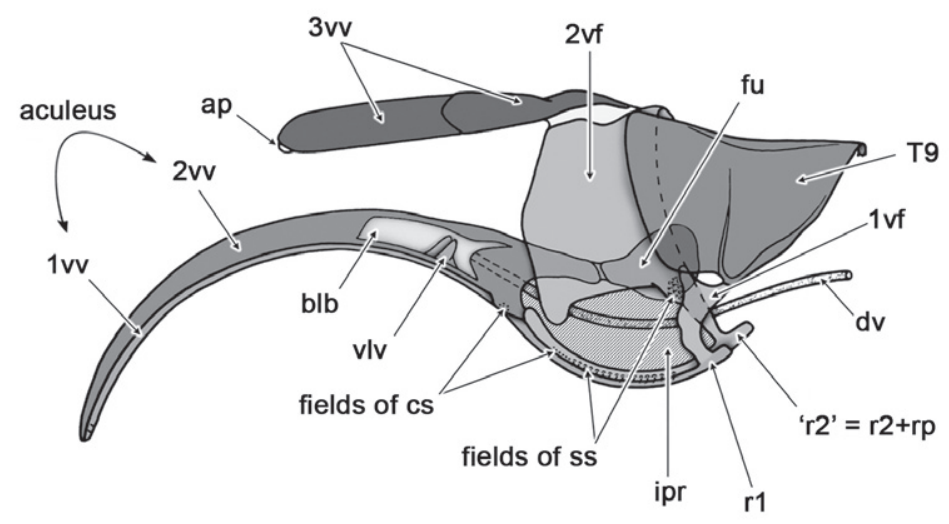

A
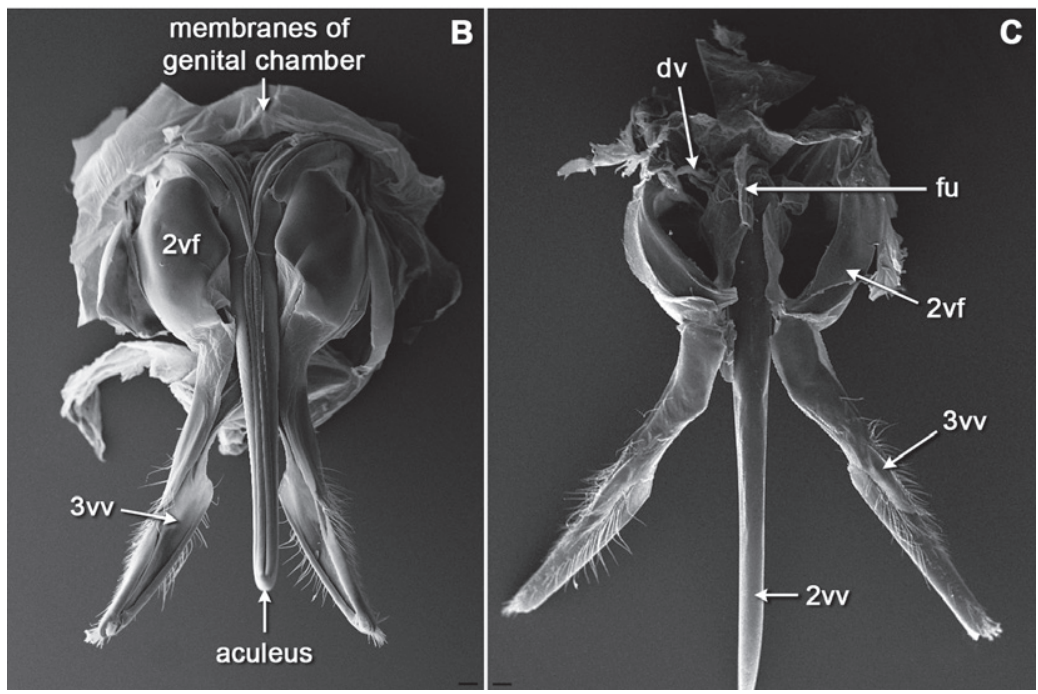

Figure I. General organization of the sting apparatus in the digger wasp Bembix rostrata: A diagram showing relative position of main parts in a lateral view (aculeus is extended ventrally, furcula is turned anteriorly; bulb is shown in longitudinal section to show valvilli, the membranous incisura postarticularis is hatched); B-C, SEM micrograph of the sting in ventral B and dorsal C views. Scale bars: $100 \mu \mathrm{m}$. 

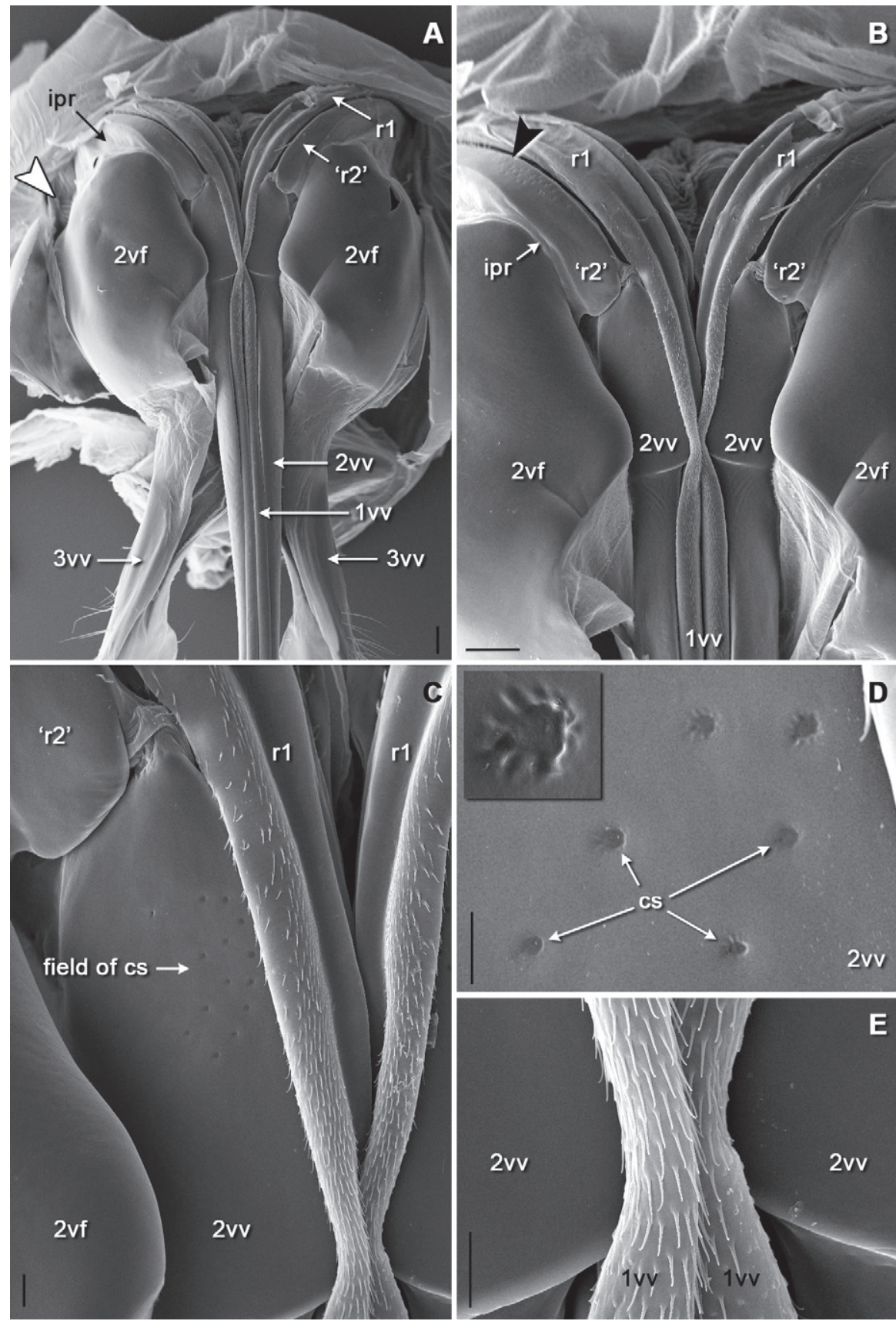

Figure 2. SEM micrographs of the sting basis, ventral view: $\mathbf{A}$ general aspects $\mathbf{B}$ basal region of the rami of both valves and of the second valvifera $\mathbf{C}$ field of campaniform sensilla on basis of the second valve D detail of the field of campaniform sensilla on basis of the second valve (one campaniform sensillum enlarged in inset) $\mathbf{E}$ distally directed microspination on membraneous regions of the first valves. Arrowhead in A shows position of the field of styloconic sensilla on the second valvifer nearby its articulation with the first valvifer (enlarged in Fig. 3B). Scale bars: $100 \mu \mathrm{m}$ in A and B; $20 \mu \mathrm{m}$ in C and E; $10 \mu \mathrm{m}$ in D. 


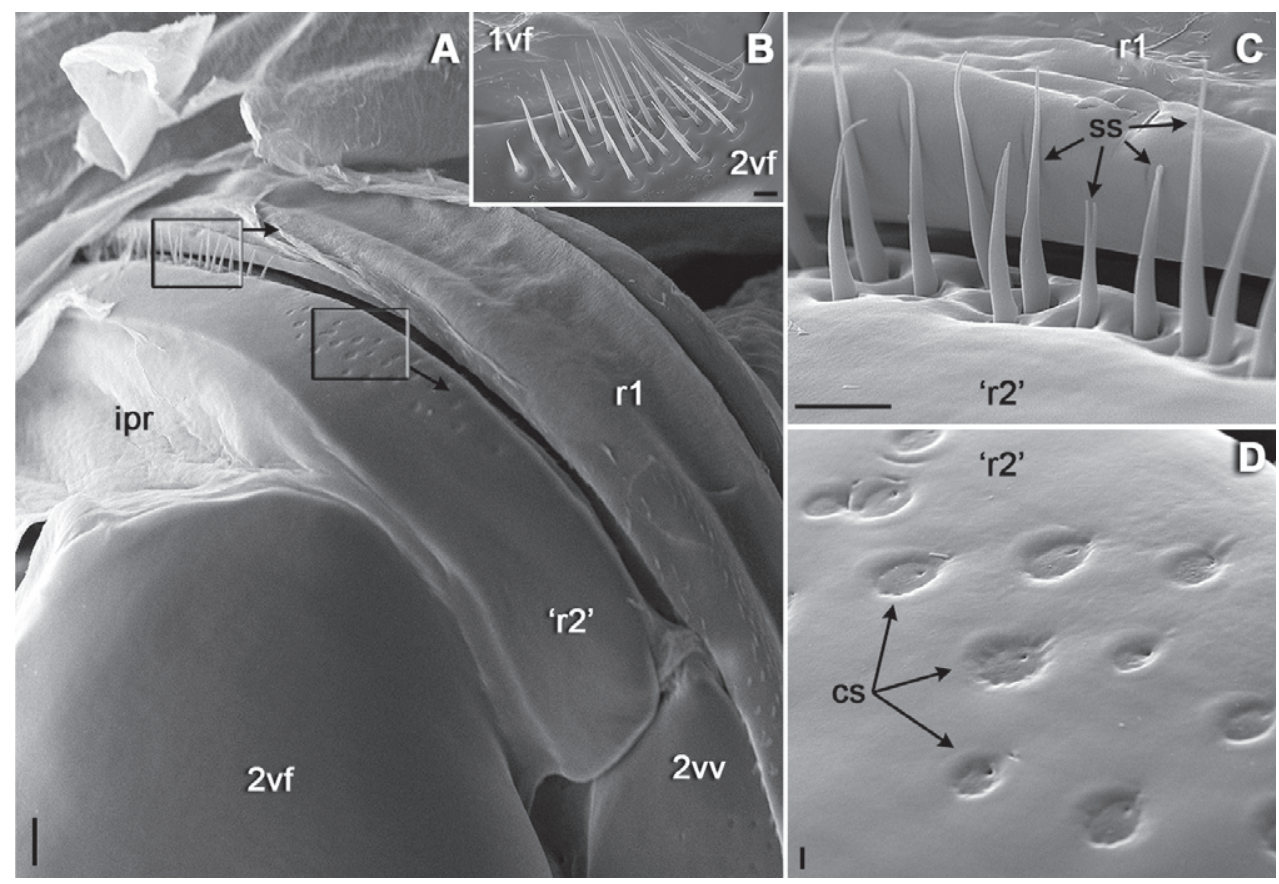

Figure 3. SEM micrographs of the sensilla on the second valvifer: $\mathbf{A}$ position of two fields of sensilla on the articular process of second valvifer, ventral view $\mathbf{B}$ field of styloconic sensilla nearby the articulation with first valvifer, lateral view $\mathbf{C}$ detail of the row of styloconic sensilla on the articular process of the second valvifer $\mathbf{D}$ detail of the field of campaniform sensilla on the articular process of the second valvifer distally to the row of styloconic sensilla. Insets in A are enlarged in C and D. Scale bars: $30 \mu \mathrm{m}$ in A; 10 $\mu \mathrm{m}$ in $\mathrm{B}$ and $\mathrm{C} ; 2 \mu \mathrm{m}$ in $\mathrm{D}$.

nal segment, thus only the apical part of the sting is visible outside at rest. The sting shaft itself (= aculeus) is massive, curved ventrally and comprises paired 1 st valvulae (= gonapophyses of $8^{\text {th }}$ segment, ventral valves and lancets) and unpaired $2^{\text {nd }}$ valvulae $(=$ medially fused gonapophyses of $9^{\text {th }}$ segment, dorsal valve, and stylet). Basal parts of the $1^{\text {st }}$ and $2^{\text {nd }}$ valvulae are continuous with long curved dorsally processes (rami) which extend to the valvifers: the $1^{\text {st }}$ ramus is connected to the $1^{\text {st }}$ valvifer (= gonangulum; triangular plate), whereas the $2^{\text {nd }}$ ramus is fused laterally with the anterior region of the $2^{\text {nd }}$ valvifer, the region called the rostral process. The $1^{\text {st }}$ and $2^{\text {nd }}$ valvulae (and their rami) form a sliding interlocking mechanism called the olistheter which comprises a groove-like ventral component (= aulax) and a tongue-like dorsal one (= rhachis). The unpaired furcula attaches to the base of the $2^{\text {nd }}$ valvula highly flexibly. The $1^{\text {st }}$ valvifer possesses two articulations: the anterior one is with the modified $9^{\text {th }}$ tergite (= quadrate plate), the posterior one with the $2^{\text {nd }}$ valvifer (= proximal part of $9^{\text {th }}$ gonocoxite). The very elastic membraneous incision (= incisura postarticularis, postincision) separates the anterior rostral process of the $2^{\text {nd }}$ valvifer from its main body. The sting itself is ensheathed by paired $3^{\text {rd }}$ valvulae (= distal part of $9^{\text {th }}$ gonocoxite or sting sheaths) when 


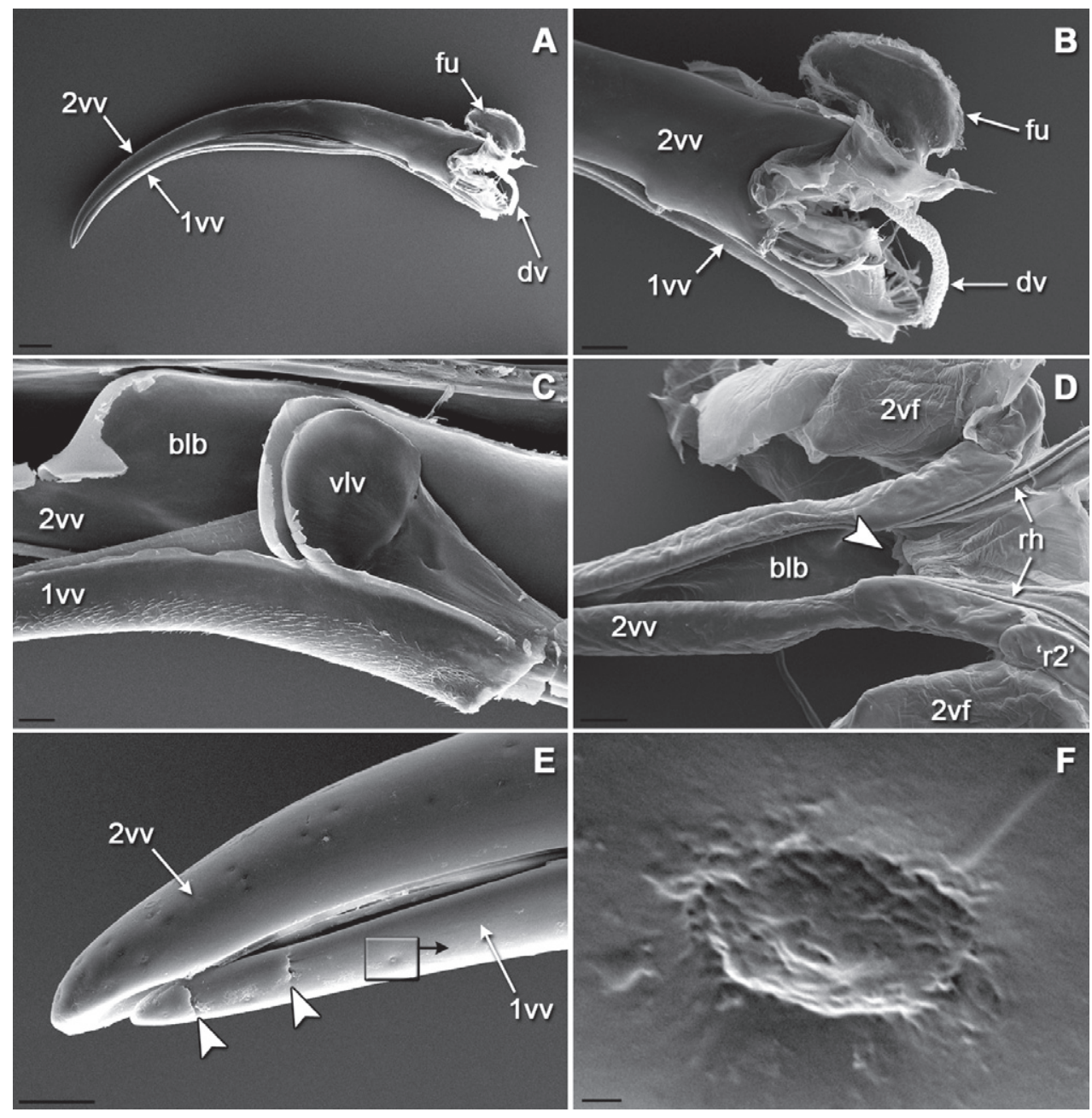

Figure 4. SEM morphology of the sting: A lateral view of sting with the furcula and venom duct B basal part of the sting $\mathbf{C}$ valvilli on the first valve positioned in the bulb of the second valve, medial view $\mathbf{D}$ ventral view of isolated second valve showing the bulb $\mathbf{E}$ lateral view of sting apex showing scattered sensilla-like structures on both valves and two subapical ridges on the first valve $\mathbf{F}$ single wrinkled sensilla-like structure that superficially resembles the secretory pores described by Nenon et al., 1995 (note characteristic contamination around the pore). Arrowheads indicate the position of the opening of the venom duct (in D) and the subapical barbs (in E). Scale bars: $200 \mu \mathrm{m}$ in A; $100 \mu \mathrm{m}$ in B and D; $30 \mu \mathrm{m}$ in $\mathrm{C}$ and $\mathrm{E} ; 300 \mathrm{~nm}$ in $\mathrm{F}$.

not in use. The modified $8^{\text {th }}$ tergite (= spiracle plate) is the outermost part of the sting apparatus and is connected neither with the sting valves nor with the valvifers.

Scanning electron microscopy. The entire external surface of the sting proper is mostly smooth, with only two subapical barbs on the $1^{\text {st }}$ valvula (Figs $4 \mathrm{~A}, \mathrm{E}$ ); however, there are numerous sensilla-like structures scattered over the entire surface, these are more numerous apically (Figs $4 \mathrm{E}, \mathrm{F}$ ). The dorsal surface of the $1^{\text {st }}$ valvula forms an 

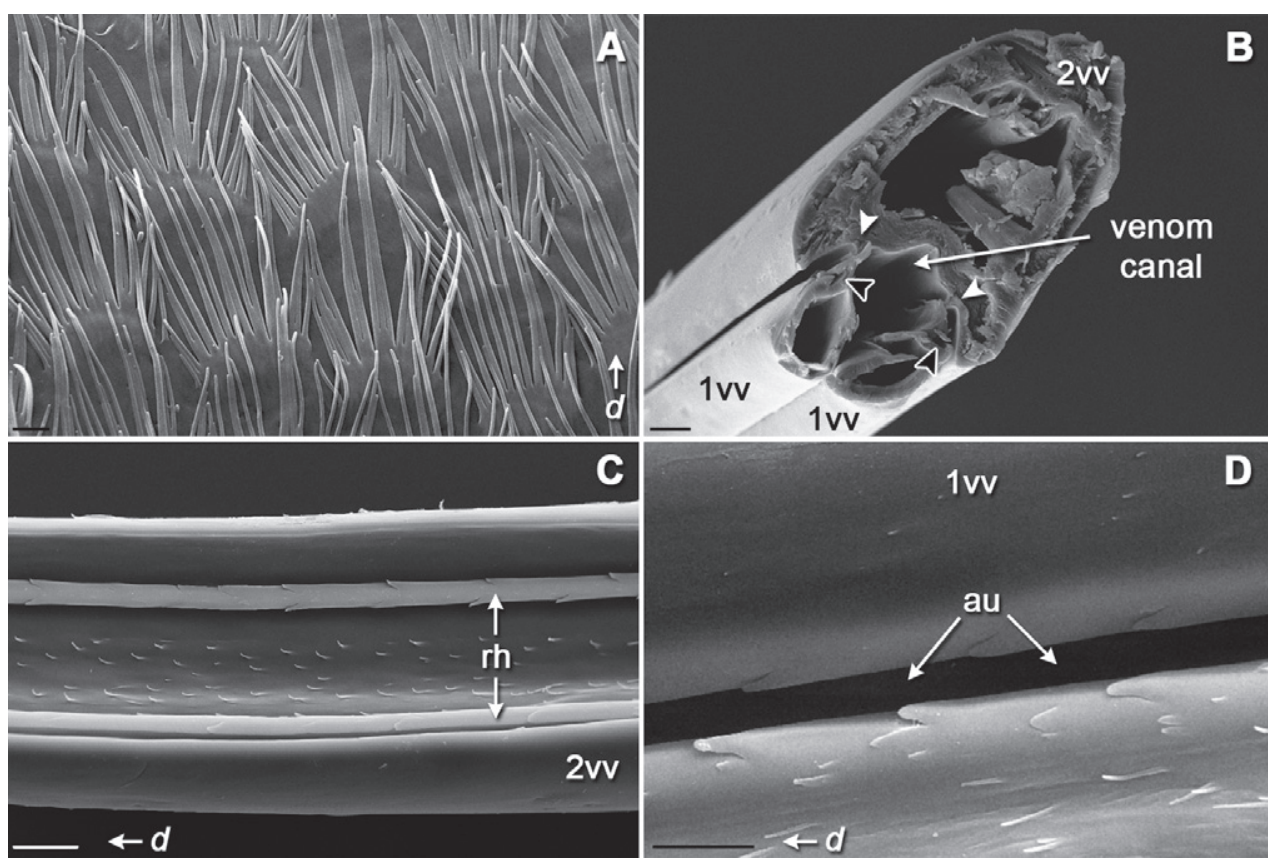

Figure 5. SEM micrographs of internal surfaces of the sting apparatus: $\mathbf{A}$ setose membrane of the genital chamber that contact the sting basis $\mathbf{B}$ transverse section of the aculeus showing position of the parts of the olistheter $\mathbf{C}$ ventral view of isolated second valve showing internal microsculpture between two rhachises $\mathbf{D}$ dorsal view of aulax of first valve. $d$, distal direction. Arrowheads in B indicate position of rhachises (white) and aulaxes (black) of the olistheter mechanism. Scale bars: $3 \mu \mathrm{m}$ in A and D; $20 \mu \mathrm{m}$ in $\mathrm{B}$ and $\mathrm{C}$.

anterior swelling where two flaps called valvilli arise (Fig. 4C). These valvilli are housed within a broadened part of the $2^{\text {nd }}$ valvula called the bulb. The venom duct enters the sting base at the anterior margin of the bulb (Figs 4A, B, D). Components of the olistheter are finely serrated, and the inner surface of the $2^{\text {nd }}$ valvula bears distally directed microtrichia (Figs 5B-D). The setose membrane of the genital chamber covers the sting base (Fig. 5A). Three fields of sensilla are found on the $2^{\text {nd }}$ valvifer. A row of styloconic sensilla is situated on the fused $2^{\text {nd }}$ ramus and rostral process (Figs $3 \mathrm{~A}, \mathrm{C}$ ). The seta of each sensillum in a row may touch the $1^{\text {st }}$ ramus, and the more the $1^{\text {st }}$ valvula protracts relative to $2^{\text {nd }}$ valvula the more sensilla contact the $1^{\text {st }}$ ramus. A field of 25-28 uniformly directed campaniform sensilla is situated more distally (Figs 3A, D). Another group of at least 35 styloconic sensilla that forms a setal plate is situated on the main sclerite of the $2^{\text {nd }}$ valvifer where it articulates with the $1^{\text {st }}$ valvifer (Figs $2 \mathrm{~A}, 3 \mathrm{~B}$ ). The seta of each sensillum in this field may touch the $1^{\text {st }}$ valvifer. A paired field of ca. 13 uniformly directed campaniform sensilla is also found on the anterolateral surface of the $2^{\text {nd }}$ valvula where it articulates with the rostral process (Figs $2 \mathrm{C}, \mathrm{D}$ ). The well sclerotized $3^{\text {rd }}$ valvula consists of two segments, the proximal and the distal (Figs 6A, C). Its inner wall is mainly membranous with a densely microsetose surface and bears 


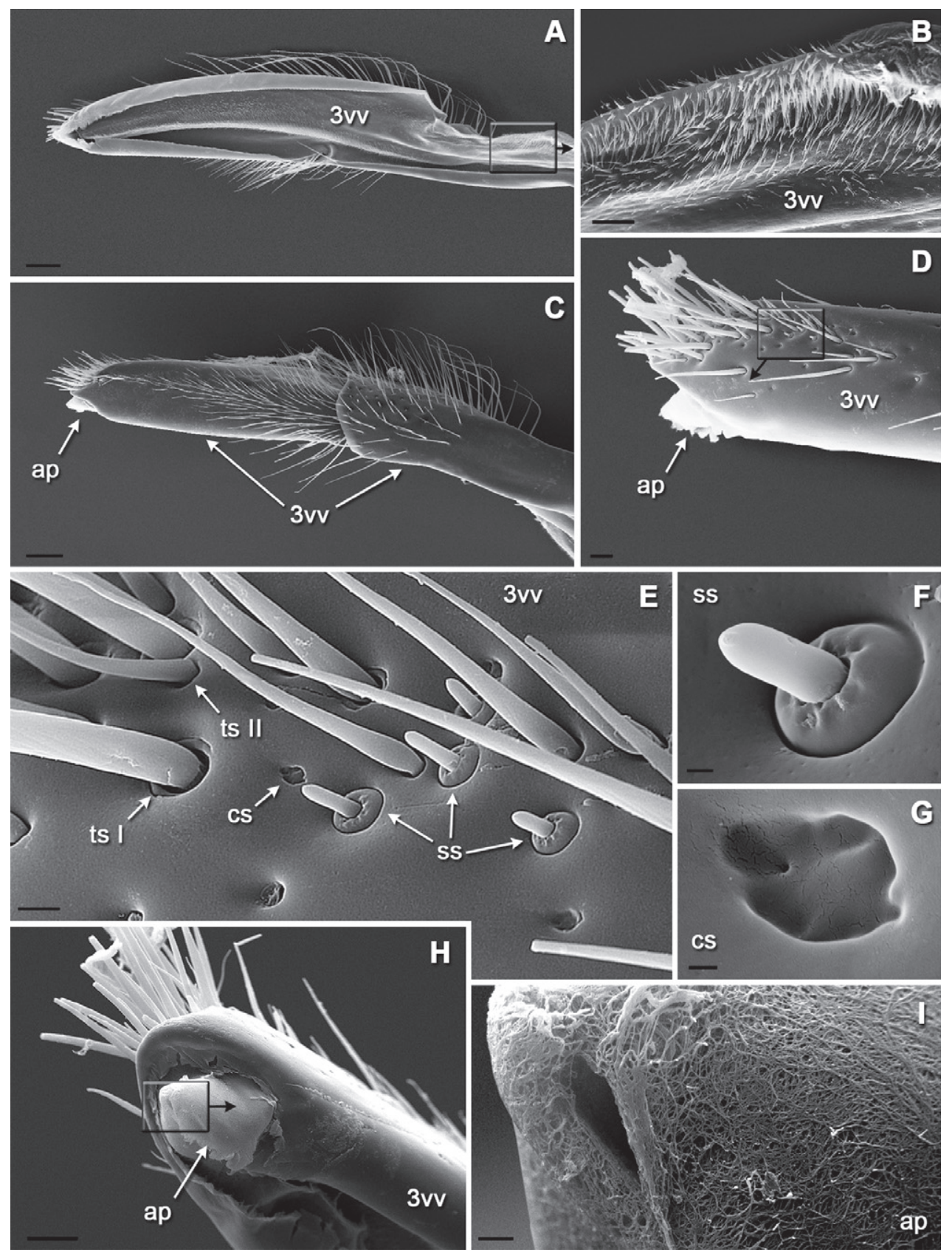

Figure 6. SEM morphology of the third valve: A medial view (inset enlarged in B) B microspination of membraneous inner wall $\mathbf{C}$ lateral view $\mathbf{D}$ apex in lateral view (inset enlarged in E) E variety of sensilla on dorsoapical surface $\mathbf{F}$ socketed styloconic sensillum with apical pore $\mathbf{G}$ campaniform sensillum $\mathbf{H}$ apex in mediodorsal view showing membranous process (inset enlarged in I) I spongiform cuticle of an apical process. Scale bars: $100 \mu \mathrm{m}$ in A and C; $20 \mu \mathrm{m}$ in B and D; $5 \mu \mathrm{m}$ in E; $1 \mu \mathrm{m}$ in F; $0.5 \mu \mathrm{m}$ in G; $30 \mu \mathrm{m}$ in $\mathrm{H} ; 2 \mu \mathrm{m}$ in $\mathrm{I}$. 
a longitudinal ridge (Figs 6A, B). Apically, the inner membrane of the $3^{\text {rd }}$ valvula forms a cone-shaped process composed of a peculiar spongy cuticle (Figs 6C, H, I). At rest, this apical process abuts closely to the dorsolateral surface of the $2^{\text {nd }}$ valvula. There are at least four morphotypes of sensilla on the $3^{\text {rd }}$ valvula (Figs $6 \mathrm{D}-\mathrm{G}$ ). Trichoid sensillum type I is socketed and has a rounded setal tip; these sensilla are aggregated apically. Trichoid sensillum type II is unsocketed and sharply pointed; these sensilla are the most abundant type, they are located all over the external surface but mostly at the apex and at the margin between proximal and distal parts of the $3^{\text {rd }}$ valvula. Campaniform sensilla are rare and scattered among trichoid ones. Socketed styloconic sensilla bear a distinct pore on their rounded setal tip; these sensilla are found only on the dorsal surface of the $3^{\text {rd }}$ valvulae between trichoid sensilla type I.

\section{Discussion}

Bembix rostrata is one of the most widely distributed and remarkable digger wasps species in Europe, and it often forms large colonies of dozen to hundred individuals. It prefers sandy and sunny habitats, where a female digs several burrows. As in most bembicine wasps, $B$. rostrata paralyzes the prey, which are predominantly large tabanid and syrphid flies, by inserting the sting through the venter of the thorax (Nielsen 1945, Evans 1957, Gadallah 2001). At this time, the sting of B. rostrata is functioning neither as an egg laying nor prey transporting device.

Radović (1985) has shown that the shape of the sting in apoid wasps is correlated with the degree of sclerotization and mobility of the prey: the wasps which prey on swift flying insects have a more strongly curved sting. This is the case in $B$. rostrata which has a markedly curved sting apparently correlated with the high speed of flight of their dipteran prey. The smooth external surface is a peculiar feature of the sting in most bembicine wasps studied so far (Gadallah and Assery 2004). Rare exceptions are three species of Bembix with barbed first valvulae: B. arenaria Handlirsch, 1893, B. oculata Panzer, 1801 (both after Gadallah and Assery 2004), and B. rostrata (this study). Apart from bembicine wasps (Crabronidae: Bembicinae), a barbed sting has been found in Sericophorus relucens F. Smith (Crabronidae: Crabroninae) which has barbs on first and second valvulae that may fasten the prey during its transportation on the sting (Radović and Sušić 1997). Interestingly, S. relucens also preys on flies. Similarly, species of the genus Oxybelus (Crabronidae: Crabroninae) possess spines on the first valvulae and transport their prey (muscid flies) impaled on the sting (Radović 1985). On the other hand, many unrelated species of apoid wasps have a barbed sting that is correlated with their preying on less sclerotized insects like caterpillars, aphids, cockroach nymphs, mantids, etc. (Radović 1985).

Several surfaces of the sting apparatus of $B$. rostrata are covered with unidirectional microstructures. The wall of the venom canal in $B$. rostrata is furnished with small microtrichia that are orientated distad. They are randomly scattered and relatively sparse, and seem to be somewhat reduced if compared with other non-aculeate hymenopter- 
ans where they form a comb-like or ctenidial pattern (Quicke et al. 1999). This egg canal microsculpture is not restricted to Hymenoptera, but can be found across several insect orders that possess an ovipositor (Austin and Browning 1981). Here it functions as a "linear ratchet", providing one-way movement of eggs along the ovipositor during longitudinal sliding of the valvulae. However, it is uncertain whether the microsculpture of the venom canal is involved in functioning of the sting in B. rostrata, which is not used for egg transport. The distally directed serration on the olistheter elements has been found in the sting of $B$. rostrata and also in the honeybee, Apis mellifera L. (Shing and Erickson 1982). The membranous cuticle of the genital chamber in B. rostrata that contacts with the sting base, as well as the inner walls of the third valvulae, are also covered with dense, distally directed microsetae of obscure functions. In parasitoid wasps, similar microsculpture on the inner walls of the third valvulae are supposed to be involved in cleaning of the ovipositor sensilla between oviposition episodes (Le Ralec et al. 1996, Quicke et al. 1999). On the other hand, a similar setose membrane in A. mellifera is known to produce and accumulate pheromones (Lensky et al. 1995, Martin et al. 2005). Noteworthy is that males of $B$. rostrata are able to differentiate between virgin or freshly copulated females and older females, by means of chemical cues which may be associated with the trunk (Schöne and Tengö 1981). It is not inconceivable that the female sting apparatus and associated structures can be a source of the aforesaid chemical cues.

The sensory equipment of the sting apparatus of $B$. rostrata is diverse. The sensilla can be divided into those that perceive intrinsic stimuli from the insect body (proprioceptors) and those detecting environmental factors (exteroceptors) (Quicke et al. 1999). Sensilla of the first type are represented in B. rostrata by two morphotypes, styloconic sensilla and campaniform sensilla, both often aggregated in fields. As in many other hymenopterans, $B$. rostrata possesses two fields of styloconic sensilla (hair plates) on the first valvifer that measure positional relationship of the first and second valvulae (Le Ralec et al. 1996, Quicke et al. 1999, Vilhelmsen et al. 2001, etc.). Two fields of campaniform sensilla have been found on the basal region of the second valvula and on its ramus for the first time in an apoid wasp. With regard to uniform transverse orientation of every sensillum in a field, they most likely function as detectors of lateral stresses and strains arising in the sting during prey penetration. Although campaniform sensilla on the third valvula are scattered, their orientation is also well-ordered. Exteroreceptors are located on the third valvula and are comprised of two morphotypes of trichoid sensilla and one morphotype of styloconic sensilla. Gadallah and Assery (2004) mentioned that trichoid sensilla on the third valvula in apoid wasps have a mechanosensory function. Possibly the differences in morphology of trichoid sensilla reflect some functional differences. The last group of sensilla that are of special interest are socketed styloconic sensilla with an apical pore, detected for the first time on the sting apparatus in an apoid wasp. It was found on the third valvula of $B$. rostrata. The presence of an apical pore implies that these sensilla are not exclusively mechanoreceptive and probably can perceive some chemical stimuli. No chemoreceptores have been recorded on the sting apparatus in apoid wasps so far. 


\section{Acknowledgements}

I am grateful to Dr. Yuri Protsenko (Kyiv National University, Ukraine) for identification of wasps, and to Prof. Neveen Samy Gadallah (Cairo University, Egypt) for her help with the literature. Dr. Wojciech J. Pulawski (California Academy of Sciences, San Francisco) is sincerely thanked for his moral support and his kind improvement of the draft version of the manuscript. I am also indebted to Prof. Laurence Packer (York University, Toronto, Canada) for careful reading of the manuscript and suggested corrections.

\section{References}

Austin AD, Browning TO (1981) A mechanism for movement of eggs along insect ovipositors. International Journal of Insect Morphology and Embryology 10(2): 93-108.

Cardinal S, Packer L (2007) Phylogenetic analysis of the corbiculate Apinae based on morphology of the sting apparatus (Hymenoptera: Apidae). Cladistics 23: 99-118.

Evans HE (1957) Studies on the comparative ethology of digger wasps of the genus Bembix. Comstock Publishing Associates, Ithaca, New York, 248 pp.

Gadallah NS (2001) A comparative morphological study of the skeletal parts of the sting apparatus in some Stizus species from Egypt (Sphecidae: Bembicinae). Egyptian Journal of Zoology 37: 255-265.

Gadallah NS, Assery BM (2004) Comparative study of the skeletal parts of the sting apparatus in some sphecid species from Saudi Arabia (Hymenoptera: Sphecidae). Linzer biologische Beiträge 36(2): 1393-1412.

Gauld ID, Bolton B (1988) The Hymenoptera. Oxford University Press, Oxford, 332 pp.

Gnatzy W, Volknandt W (2000) Venom gland of the digger wasp Liris niger: morphology, ultrastructure, age-related changes and biochemical aspects. Cell and Tissue Research 302(2): 271-284.

Le Ralec A, Rabasse JM Wajnberg E (1996) Comparative morphology of the ovipositor of some parasitic Hymenoptera in relation to characteristics of their hosts. The Canadian Entomologist 128: 413-433.

Lensky Y, Cassier P, Tel-Zur D (1995) The setaceous membrane of honey bee (Apis mellifera) workers sting apparatus: structure and alarm pheromone distribution. Journal of Insect Physiology 41: 589-595.

Martin SJ, Dils V, Billen J (2005) Morphology of the Dufour gland within the honey bee sting gland complex. Apidologie 36: 543-546.

Nénon J-P, La Lannig J, Kacem N, Barbier R, Allo M-R (1995) Micromorphologie de l'ovipositeur des Hyménoptères et évolution des symphytes phytophages aux apocrites parasitoïdes. Comptes rendus de l'Académie des sciences Paris, Sciences de la vie/Life Sciences 318: 1045-1051.

Nielsen ET (1945) Moeurs des Bembex. Monographie biologique avec quelques considérations sur la variabilité des habitudes. Spolia Zoologica Musei Hauniensis 7: 1-174. 
Oeser R (1961) Vergleichend-morphologische Untersuchungen über den Ovipositor der Hymenopteren. Mitteilungen aus dem Zoologischen Museum in Berlin 37: 3-119.

Packer L (2003) Comparative morphology of the skeletal parts of the sting apparatus of bees (Hymenoptera: Apoidea). Zoological Journal of the Linnean Society 138: 1-38.

Quicke DLJ, Fitton MG, Ingram SN (1992) Phylogenetic implications of the structure and distribution of ovipositor valvilli in the Hymenoptera (Insecta). Journal of Natural History 26(3): 587-608.

Quicke DLJ, LeRalec A, Vilhelmsen L (1999) Ovipositor structure and function in the parasitic Hymenoptera with an exploration of new hypotheses. Atti dell'Accademia Nazionale Italiana di Entomologia, Rendiconti 47: 197-239.

Radović IT (1985) Morphology and adaptive value of the sting apparatus of digger wasps (Hymenoptera : Sphecidae). Acta entomologica Jugoslavica 21 (1-2): 61-73.

Radović IT, Sušić S (1997) Morphological characteristics of the sting and prey carriage mechanism in Sericophorus relucens F. Smith (Hymenoptera: Sphecidae: Larrinae). Proceedings of the Entomological Society of Washington 99(3): 537-540.

Rahman MH, Fitton MG, Quicke DLJ (1998) Ovipositor internal microsculpture and other features in doryctine wasps (Insecta, Hymenoptera, Braconidae). Zoologica Scripta 21(4): 333-343.

Rasnitsyn AP (1980) Origin and evolution of Hymenoptera. Trudy paleontologicheskogo instituta akademii nauk SSR [Transactions of the Paleontological Institute, Academy of Science, USSR] 174. Nauka Press, Moscow, 192 pp. (in Russian).

Schöne H, Tengö J (1981) Competition of males, courtship behaviour and chemical communication in the digger wasp Bembix rostrata (Hymenoptera, Sphecidae). Behaviour 77(1-2): 44-65.

Scudder GGE (1961) The comparative morphology of the insect ovipositor. Transactions of the Royal Entomological Society of London 113: 25-40.

Shing H., Erickson EH (1982) Some ultrastructure of the honeybee (Apis mellifera L.) sting. Apidologie 13: 203-213.

Smith EL (1970) Evolutionary morphology of the external insect genitalia. 2. Hymenoptera. Annals of the Entomological Society of America 63: 1-27.

Snodgrass RE (1956) Anatomy of the honey bee. Cornell University Press, Ithaca, 334 pp.

Vilhelmsen L (2000) The ovipositor apparatus of basal Hymenoptera (Insecta): phylogenetic implications and functional morphology. Zoologica Scripta 29 (4): 319-345.

Vilhelmsen L, Isidoro N, Romani R, Basibuyuk HH, Quicke DLJ (2001) Host location and oviposition in a basal group of parasitic wasps: the subgenual organ, ovipositor apparatus, and associated structures in the Orussidae (Hymenoptera, Insecta). Zoomorphology 121: 63-84. 